Journal of Contemporary Research in Business, Economics and Finance

ISSN: 2641-0265

Vol. 2, No. 4, pp. 83-94

2020

Publisher: Learning Gate

DOI: 10.33094/26410265.2020.24.83.94

(C) 2020 by the authors; licensee Learning Gate

\title{
Trade Unions' Reactions to Non-implementation of Collective Agreements in the Lagos State Public Sector
}

\author{
Elegbede Sikirulahi Tunde \\ Department of Employment Relations and Human Resource Management Faculty of Management Sciences University of Lagos Akoka, \\ Nigeria. \\ Email: telegbede@unilag.edu.ng \\ Samuel Chidiebere Okeke \\ Department of Employment Relations and Human Resource Management Faculty of Management Sciences University of LagosAkoka, \\ Nigeria. \\ Email: samuelokeke2016@yahoo.com \\ Jamiu Salam Abiodun \\ Department of Management Yaba College of Technology, Nigeria.
}

Received: 8 September 2020; Revised: 12 October 2020; Accepted: 21 October 2020; Published: 29 October 2020

\begin{abstract}
The objective of the study is to examine trade unions' reactions to the non-implementation of collective agreements in the Lagos State public sector. The non-implementation of collective agreements between employers and trade unions has been the source of strikes and all forms of industrial conflict in the work place. The study employed cross sectional design and adopted survey method as research strategy. The reliability of the research instrument was determined using the Cronbach's Alpha and the outcome was 0.796. It was hypothesised that nonimplementation of collective bargaining agreement does not affect trade unions' reactions in the Lagos State public sector. A regression analysis of the data was carried out using SPSS version 20, considering the trade unions reactions as the criterion variable and non-implementation of collective bargaining agreement as the predictor variable. The result of the regression indicated the predictor explained $4.8 \%$ of the variance in the criterion variable. $\left(R^{2}=0.48 ; F(1,328)=16.435, p<0.05\right)$. It was found that non-implementation of collective bargaining agreement significantly affect trade unions' reactions in the Lagos State public sector at $(\beta=0.219, p<0.05)$. The outcome of the this study revealed that the non-implementation of collective bargaining agreements has implications for trade unions' reactions. Arising from the findings of the study, it is hereby recommended that to foster cordial labour- management relationship and to promote industrial harmony, governments at all levels should honor collective agreements.
\end{abstract}

Keywords: Trade unions' reactions, Collective agreements, Lagos State, Public Sector, Industrial harmony, non-implementation, Strikes, Industrial conflict.

\section{Introduction}

Collective bargaining performs a lot of functions in the employment relationship. It is a means for determining employment terms and conditions as well as a means for resolving conflict between labour and management inter alia. Collective bargaining refers to dispute in progress because conflict is usually inevitable at any stage of the collective bargaining process (Fajana, 2002). In the Lagos State public sector, amendment of collective agreement during implementation stage accounts for most of the disputes that occur in the public sector. Within the principles of neo-classical economics, collective 
bargaining process is perceived as a distortion to the competitive and perfect market system (Kaufman, 2013).

However, neo-classical economists' analyses of wage determination through the competitive labour market did not take into account the very important fact, that many labour markets are not competitive. There are considerable distortions caused by non-competitive institutional elements such as trade unions, and collective bargaining (Fajana., 2000). The alterations of the labour market can bring about the imposition of the unions on firms, or the firms on union. But an alternative approach which involves both the unions and firms is what is referred to as collective bargaining (Fajana., 2000). The success of collective bargaining depends on the strength of collectivity of workers, and the aggregation of several individuals' interests into a single programme of demands.

However, the unions' objective is to ensure through collective bargaining higher wages and better conditions of work. Freeman and Medoff (1985) opine that; "trade unions bargain for higher wages, equal pay, fair working conditions, and employment protection”.

The non-implementation of collective agreements between employers and employees represented by trade unions has been the source of strikes and all forms of industrial conflict in the work place. These conflict are inimical to individual, organisational and society progress. Some of the adverse implications of conflict arising from non-implementation of collective agreement include strain in the employment relationship, poor organisational performance and reduced profitability as well lack of goodwill or reputation in the eyes of the public and numerous stakeholders.

The objective of the study is to examine trade unions' reactions to the non-implementation of collective bargaining agreements in the Lagos State public sector.

\section{Literature Review}

This section examines the theoretical frame work of the study and the empirical review of literature.

\subsection{Theoretical Framework of the Study}

\subsubsection{Chamberlain and Kuhn Bargaining Theory}

Chamberlain and Kuhn (1965) viewed collective bargaining from three perspectives which represent different stages in the development of the collective bargaining process. The three perspectives are: means of contracting for the sale of labour, form of industrial governance; and a system of industrial management. These perspectives are respectively called the marketing theory, the governmental theory and the managerial theory.

The bargaining theory suggests that wage determination process should be subjected to bargaining process to benefit the industrial relations actors at the bipartite and tripartite levels. However, most often, the use of this wage machinery necessitated the government to use its prerogative to amend collective agreement to its advantage which results in trade unions' reactions in the form of protests, demonstrations and strike. For instance, Academic Staff Unions of Universities (ASUU) was on strike for six months in 2014 over the non-implementation of the 2009 collective agreement, National Unions of Research Institutions (NURI) was on strike for over twelve months over the non-implementation of the 2008 agreement on conditions of work, remuneration and unpaid allowances. For instance, in the year 2013, a collective agreement was reached between the Federal Government of Nigeria and the Nigeria Medical Association on the new Consolidated Medical Salary Scale. This was done without consultation with the various state governments. While Federal government implemented the new salary scale Lagos State Government refused to do so on the ground that it will cost 1.8 billion Naira to implement. Most state governments, in the same vein, drew from the example of the Lagos state government because the new salary scheme was conceived as a huge burden they are not prepared to carry. This account for the industrial action embarked upon by the Medical Doctors in Lagos State for over seven months (Guardian Newspaper, 2013).

Journal of Contemporary Research in Business, Economics and Finance
ISSN: $2641-0265$
Vol. 2, No. 4, pp. $83-94,2020$
DOI: $10.33094 / 26410265.2020 .24 .83 .94$
C) 2020 by the authors; licensee Learning Gate




\subsubsection{Adams Stacy Equity Theory}

Equity theory focuses on people's feelings of how fairly they have been treated in comparison with the treatment received by others. Equity theory is very relevant to this study because fairness is always the key concern in any pay decision. The equity theory is based on exchange theory as advocated by Adams (1965). Social relationships involve an exchange process. Workers determine the perceived equity of their own position. Their feelings about the equity of the exchange are affected by the treatment they receive when compared with what happens to their significant others or colleagues. Most exchanges involve a number of inputs and outcomes according to how they perceive their importance. When there is an unequal comparison of ratios, the person experiences a sense of inequity. Equity theory of wage determination seeks to eliminate tension and perceived inequality among workers in the organisation by attempting to change the input of the worker and the object of comparison. The manager can adopt two courses of action; first, outcomes can be changed by increasing the pay of the worker and second, additional perks or improved working conditions or by instigating a person to leave through transfer, resignation or as an extreme measure which is dismissal (Mullins, 2007). Applying this concept to the Lagos State public sector wage determination, the government often set up wage commissions/tribunal or imposed minimum wage to reduce tension but this may create inequity in pay and conditions of employment. This may cause negative reactions from workers. For instance, the medical doctors' protest to opt out of the Universal Grading and Salary Structure (UGSS) because of the decline in their status, prestige and earning power in 1990 (Fajana, 2002; Fashoyin, 1992; Otobo, 1986). Equity theory of wage determination failed to recognize the need for and the inevitability of pay differentials and collectively bargained wages.

\subsection{Empirical Review of Literature}

The study of Cramton, Gunderson, and Tracy (1999) examined the impact of collective bargaining process on strikes and wages. The outcome of the study revealed that collective bargaining influences strikes and wages. Though the study of Cramton et al. (1999) revealed that there is a relationship between collective bargaining, strike and wages but failed to determine the possible outcomes of this relationship on the major actors in industrial relations.

Corroborating the findings of Cramton et al. (1999); Omisore (2011) observed that in Nigeria, events have shown that government has a poor attitude to workers' demands hence, it breaches collective agreement signed with labour unions. In Omisore (2011) view this has created the general belief that the only language that the government understands on labour matters is an industrial action or strikes. Aligning with Omisore (2011); Iwunze (2013) asserts that the current labour policy regarding the legal status of collective policy within the framework of the Nigerian law is potentially disruptive of industrial peace and harmony and seems to cause reactions from trade unions in the public sector.

Kohn and Lembcke (2007) employed linked employer-employee data from the German Structure of Earnings Survey. Their study provides a comprehensive picture of the wage structure in three wagesetting regimes prevalent in the German system of industrial relations. The authors analyze wage distributions for various labour market subgroups by means of kernel density estimation, variance decompositions, and individual and firm-level wage regressions. Their results show that Unions' impact through collective bargaining and firm-level bargaining mainly works towards a higher wage level and reduced overall and residual wage dispersion. However, Kohn and Lembcke (2007) did not address the other collective bargaining related issues such as the influence of collective bargaining on trade unions reactions.In line with the findings of Kohn and Lembcke (2007); Klaff and Ehrenberg (2003) study examined collective bargaining effect on wages and strike in the America universities and colleges.

Using data from a 1997-98 survey conducted by the Association of Higher Education Facilities Officers and other sources, Klaff and Ehrenberg (2003) investigate how union coverage affect staff salaries in 163 colleges and universities in the United State of America. Their results show that where faculty members are covered by a collective bargaining agreement, unionized staff members appear to 
enjoy an additional salary gain of 2-3\%. However, the work of Klaff and Ehrenberg (2003) is limited in scope and it only examines the impact of collective bargaining on wages in American universities while leaving out other public sector's organisations and they also failed to examine the influence of collective bargaining on trade unions' reactions.

Similarly, the findings by Fairris (2003) in his study to determine the impact of trade unions on wages was able to establish positive relationship between unions' bargaining power and trade unions' reactions. The objective of his study was to examine the effect of union bargaining power in reducing wage dispersion among its members. Using a variance analysis between 1984 and 1996 the results indicate that unions were a strongly equalizing force affecting the dispersion of wages in 1984, but were only half as effective at reducing wage inequality in 1996. He revealed from in his study that unions were able to increase wages and reduce wage inequality in 1984 owing to their membership strength and the power of the union at the collective bargaining table.

Fairris (2003) study shows some similarity with the current study in terms of objective but differs in term of methodology. In his attempt to study the effect of collective bargaining power of union in reducing wage dispersion, Fairris (2003) posits that collective bargaining significantly influenced trade unions' reactions along with reduction in wage dispersion among members. But the study of Fairris (2003) failed to examine the direct impact of collective bargaining on trade unions' reactions. Fairris (2003) in his study did not consider the significant relationship between collective bargaining and trade unions 'reactions.

Ferreiro (2004) examined decentralised versus centralised collective bargaining and to examine the efficacy of the collective bargaining structure in Spain. Ferreiro (2004) posits that collective action gives workers a bargaining power that will be used to get "excessive "wages ,that is, wages higher than the market-clearing wages. This study tests the validity that collective bargaining structures in Spain are determinant factor of the rates of unemployment and inflation. The results show that pay increases through collective bargaining procedures do not bring about unemployment and inflation. However, the study of Ferreiro (2004) failed to consider the micro and macro-economic effect of collective bargaining on wages as well as the rest of the contents of collective bargaining agreement and other institutional elements of the labour market.

Cahuc, Postel-Vinay, and Robin (2006) observed in their empirical study of on wage bargaining with the on-the-job search as they opine that wage bargaining may not bring about wage increase. They adopted an equilibrium model with strategic wage bargaining and on-the-job search and used it to examine the determinants of wages in France. The authors concluded that there are three essential determinants of wages from their equilibrium model. These are productivity, competition between employers resulting from on-the-job search, and the workers' bargaining power. The authors found that between-firm competition was a significant determinant of wages. The findings of Cahuc et al. (2006) are germane to the private sector and in most developed economies where it is possible to have between -firm competitions. In the public sector, especially in most of the developing economies where the public sector enjoys monopoly power and therefore between-firm competition, wage bargaining will be a dominant factor in wage determination.

Kahn (1997) investigated collective bargaining and industry wage levels using microdata and quantile regression techniques for the United States, Britain, West Germany, Austria, Sweden and Norway in the 1980s. The study set out to examine the effect of collective bargaining on the inter- wage industry among developed countries. The study found that United States has higher industry wage differentials and union wage effects than other countries, with particularly large impacts at the bottom of the distribution. European wage structures are more compressed at the bottom for both non-union and union workers in United States, with larger differences for non-union workers. These findings suggest more coordination, contract extension and spillover to non-union workers, and more binding industry wage floors outside the United States.

Kahn (1997) study revealed that collective bargaining has positive impact on wages in developed countries, however, his study is not a total reflection of the impact of collective bargaining on trade 
unions' reactions because the study focused only on the effect of strike on wage increase. In a comparative analysis of wage determination in unionised and non-unionised organisations in Nigeria, Fapohunda (2012) examined wage determination in unionised and non-unionised organisations. The results indicate that a significant relationship exists between wage levels and sunionisation. Also, the study clearly revealed that workers in non-unionised organisations do not necessarily earn less than those in unionised organisations. The study also found that the level of wages is related to the ability of union leaders to negotiate skillfully. Contrary to the study of Fairris (2003); Cramton et al. (1999); Ferreiro (2004) argues that unionisation and collective bargaining do not have a significant impact on general conditions of service. The study also revealed that companies exploit the freedom of association and non-unionisation options to engage more workers in decentralised and individualised employment relations rather than the collectivism associated with trade unionism.

The study of Blakemore, Hunt, and Kiker (1986) on collective bargaining and union membership effects on the wages of male youth revealed that there is a wide gap between the wages of unionised workers and non-unionised workers. Although the forte of their study is to demonstrate that the nonunion wage differentials consists of two effects. The study was able to establish the first effect that wage differential exists between a non-union worker in a collective bargaining unit and the wage paid to a comparable worker not covered by a bargaining agreement. Blakemore et al. (1986) claim that this effect arises from the monopoly power of organised labour. The second effect discovered is that wage differential exists between union and non-union workers in collective bargaining units. From the study, the authors found that the second effect is attributed to economic benefits that unionism brings to its members.

However, the study of Blakemore et al. (1986) is limited in scope because it examined only the collective bargaining effects on wages among male youth. This may not be a true reflection of the actual effect of collective bargaining on wages owing to the fact that the study did not put into consideration other group of workers within the collective bargaining unit. One major importance of their study is that it established by using empirical evidence that collective bargaining and union membership bring about higher wages than the wages of non - union workers through the use of strike.

In conclusion the studies of Fairris (2003); Cramton et al. (1999); Ferreiro (2004) and Blakemore et al. (1986) revealed that there is positive relationship between the non-implementation of collective bargaining agreement and trade unions' reactions. Cramton et al. (1999) argued that strikes and wages are substantially influenced by labour policy.

The study of Cahuc et al. (2006) and Fapohunda (2012) laid stress on workers' productivity, bargaining power and between-firm competition as significantly related to workers' reactions rather than collective bargaining. However, the study of Cahuc et al. (2006) can be further criticised on the groundsthat all the variables in their equilibrium model can be considered as sub-variables under collective bargaining especially workers' productivity and bargaining power of the workers.

\subsection{Research Hypothesis}

Ho: Non-implementation of collective bargaining agreement does not affect trade unions' reactions in the Lagos State public sector.

\section{Research Methods}

The population for study under investigation consists of all staff in the employment of Lagos State Government. The population of this study is 112,217 (Training and Pension Annual Digest Bulletin, 2013) consisting of members of existing trade unions in Lagos State Public Sector such as Nigeria Civil Service Unions (NCSU) representing workers under the Civil Services Commission, Association of Senior Civil Servants of Nigeria ( ASCN) representing senior civil servants under the Civil Services Commission and also in the Parastatals, Nigeria Medical Association (NMA) representing workers in the Health Service Commission, Nigeria Union of Teachers (NUT) representing workers in the Teaching Service Commission and Lagos State Universal Basic Education Board (SUBEB), National 
Union of Local Government Employees (NULGE) representing workers in the Local Government Service Commission.

Table-1.

Study Population.

\begin{tabular}{l|l|c}
\hline Units & Trade unions & Population \\
\hline Health Service Commission & Nigerian Medical Association & 10,768 \\
\hline Teaching Service & Nigerian Union of Teachers & 24,194 \\
\hline Civil Service Commission & $\begin{array}{l}\text { National Civil service unions of Nigeria } \\
\text { and Association of Senior Civil Servants of } \\
\text { Nigeria }\end{array}$ & 17,858 \\
\hline $\begin{array}{l}\text { Local Government Service } \\
\text { Commission }\end{array}$ & $\begin{array}{l}\text { National Union of Local Government } \\
\text { Employees }\end{array}$ & 25,300 \\
\hline SUBEB & Nigerian Union of Teachers & 26,393 \\
\hline Parastatal & Parastatal & 7,704 \\
\hline Total & \multicolumn{2}{l}{112,217} \\
\hline
\end{tabular}

Source: Human Resource Unit, Lagos State Public Service office, 2020.

The sample size was determined from the population of the study using the Yamane (1967) formula as stated below:

Where $\mathrm{n}=$ sample size, $\mathrm{N}=$ total or grand population, $\mathrm{e}=95 \%$ confidence level and $\mathrm{p}$-value of 0.05 are assumed

$\mathrm{n}=112,217 / 1+112,217(\mathrm{e}) 2, \mathrm{n}=112,217 / 1+280.54$

$\mathrm{n}=399$

The Yamane (1967) sample size determination formula was used to minimise sampling error and ensure the quality of data collected.

Owing to the nature of the composition of the Lagos State Public Sector, the study adopted stratified random sampling procedures. The stratified random sampling was used to divide Lagos state public sector into six strata; Health Service Commission, Teaching Service Commission, Civil Service Commission, Local Government Service Commission, State Universal Basic Education Board, and Parastatals. This is because of the heterogeneity of the population. Stratified sampling technique helps to sample heterogeneous population into subpopulation (stratum) independently, Kish (1965) and Barbie (2007).

Samples were allocated to each stratum using Yamane (1967) simplified formula for proportion below: where $\mathrm{n}^{-}=$unit sample, $\mathrm{n}=$ sample size, $\mathrm{N} 1=$ Unit population, $\mathrm{N}=$ Grand Population. Units sample size for health service commission can be determine as follows:

$\mathrm{n}^{-}=400(10768) / 112217$

$\mathrm{n}^{-}=38$. By applying the Yamane (1967) formula to other unit, sample size allocated to each unit was determined as shown in the sampling frame in Table 2.

Relevant data for this study were collected through the survey instrument. The questionnaire was used to solicit opinions of respondents and extract information on the relationship between government wage policy and trade unions' reactions in the public sector. The choice of the questionnaire as the major instrument of data collection was because it is an excellent vehicle for measuring attitudes and orientation in a large population. It also helped the researcher to collect data for describing the respondents which are difficult to observe directly (Barbie, 2007). In-depth interview was also conducted as follow-up with few individuals who participated in the survey and are directly responsible for wage determination on behalf of government and trade unions in Lagos State Public Sector. The interview helped to improve and validate the quality of data collected through questionnaires. 
Table-2.

Sampling Frame.

\begin{tabular}{l|l|c|c}
\hline Units & Trade Unions & Population & Sample Selected \\
\hline Health Service Commission & Nigerian Medical Association & 10,768 & 38 \\
\hline Teaching Service & Nigerian Union of Teachers & 24,194 & 86 \\
\hline Civil Service Commission & $\begin{array}{l}\text { National Civil service unions of Nigeria and } \\
\text { Association of Senior Civil Servants of Nigeria }\end{array}$ & 17,858 & 64 \\
\hline $\begin{array}{l}\text { Local Government service } \\
\text { commission }\end{array}$ & National Union of Local Government Employees & 25,300 & 90 \\
\hline SUBEB & Nigerian Union of Teachers & 26,393 & 94 \\
\hline Parastatals & $\begin{array}{l}\text { National Civil service unions of Nigeria and } \\
\text { Association of Senior Civil Servants of Nigeria }\end{array}$ & 7,704 & 27 \\
\hline Total & & 112,217 & 399
\end{tabular}

Source: Field survey, 2020.

\section{Results}

Table-3.

Respondents' views on collective bargaining.

\begin{tabular}{|c|c|c|c|c|c|c|c|c|c|c|}
\hline \multirow[t]{2}{*}{ Collective Bargaining } & \multicolumn{2}{|c|}{ SD } & \multicolumn{2}{|c|}{ D } & \multicolumn{2}{|c|}{$\mathbf{U}$} & \multicolumn{2}{|c|}{$\overline{\mathbf{A}}$} & \multicolumn{2}{|c|}{ SA } \\
\hline & Freg & $\%$ & Freq & $\%$ & Freq & $\%$ & Freq & $\%$ & Freq & $\%$ \\
\hline $\begin{array}{l}\text { Collective bargaining is the } \\
\text { most preferred wage } \\
\text { determination machinery in the } \\
\text { public sector }\end{array}$ & 85 & 25.8 & 174 & 53 & 20 & 6.1 & 38 & 12 & 12 & 3.6 \\
\hline $\begin{array}{l}\text { Implementation of collective } \\
\text { agreement is effective in the } \\
\text { public sector }\end{array}$ & 31 & 9.4 & 145 & 44 & 41 & 13 & 84 & 26 & 28 & 8.5 \\
\hline $\begin{array}{l}\text { Government has the right to } \\
\text { amend, accept and reject } \\
\text { collective agreement }\end{array}$ & 52 & 15.8 & 182 & 55 & 19 & 5.8 & 50 & 15 & 26 & 7.9 \\
\hline $\begin{array}{l}\text { Government regulation of } \\
\text { collective bargaining is essential }\end{array}$ & 49 & 14.9 & 202 & 61 & 32 & 9.7 & 32 & 9.7 & 14 & 4.3 \\
\hline $\begin{array}{l}\text { Collective bargaining is an } \\
\text { effective machinery in the public } \\
\text { sector }\end{array}$ & 45 & 13.7 & 195 & 59 & 20 & 6.1 & 47 & 14 & 22 & 6.7 \\
\hline $\begin{array}{l}\text { Implementation of collective } \\
\text { agreement is satisfactory to } \\
\text { workers }\end{array}$ & 81 & 24.6 & 151 & 46 & 42 & 13 & 40 & 12 & 15 & 4.6 \\
\hline $\begin{array}{l}\text { Government always relies on } \\
\text { collective bargaining }\end{array}$ & 22 & 6.7 & 131 & 40 & 49 & 15 & 105 & 32 & 22 & 6.7 \\
\hline $\begin{array}{l}\text { Dispute usually arises from } \\
\text { collective bargaining process }\end{array}$ & 49 & 14.9 & 164 & 50 & 24 & 7.3 & 73 & 22 & 19 & 5.8 \\
\hline $\begin{array}{lcr}\text { Government } & \text { seldom } & \text { use } \\
\text { collective } & \text { bargaining } & \text { to } \\
\text { determine } & \text { conditions } & \text { of } \\
\text { employment } & & \end{array}$ & 80 & 24.3 & 133 & 40 & 36 & 11 & 74 & 23 & 6 & 1.8 \\
\hline $\begin{array}{l}\text { Violations of workers' right } \\
\text { always arises from failure of } \\
\text { collective bargaining process }\end{array}$ & 96 & 29.2 & 161 & 49 & 32 & 9.7 & 31 & 9.4 & 9 & 2.7 \\
\hline
\end{tabular}

Source: Field Survey, 2020

Note: SD = Strongly Disagree (1); D = Disagree (2); U = Undecided (3); A = Agree (4); SA = Strongly Agree (5).

Journal of Contemporary Research in Business, Economics and Finance
ISSN: $2641-0265$
Vol. 2, No. 4, pp. $83-94,2020$
DOI: $10.33094 / 26410265.2020 .24 .83 .94$
C) 2020 by the authors; licensee Learning Gate


The questionnaire was structured into two sections; section A and B. Section A was used to seek biographical data of the respondents such as age, sex, salaries, employment status, length of service and positions in the organization. Section $B$ was used to $x$-ray relevant information on government wage policy and collective bargaining in the Lagos State Public.

\subsection{Respondents' Views on Collective Bargaining is the Most Preferred Wage Determination Machinery in the Public Sector}

Table 3 revealed that 78.7 percent of the respondents disagreed that collective bargaining is the most preferred wage determination machinery in the public sector, 15.2 percent of the respondents agreed that collective bargaining is the most preferred wage determination machinery in the public sector, while 6.1 percent of the respondents are undecided whether or not collective bargaining is the most preferred wage determination machinery in the public sector. Based on majority views, these distributions established that government preferred the use of other wage determination machinery to collective bargaining. Government relies on wage commission, minimum wage and administrative policy to determine wages most often than collective bargaining. In the public sector, government makes use of the wage determination policy that is best in a given situation.

\subsection{Respondents' Views on Implementation of Collective Agreement is Effective in the Public Sector}

Table 3 revealed that 53.5 percent of the respondents disagreed that implementation of collective agreement is effective in the public sector. This is followed by 34 percent of the respondents who agreed that the implementation of collective agreement is effective in the public sector while, 12.5 percent of the respondents are undecided. Based on majority views, these distributions revealed that the implementation of collective agreement is not effective in the public sector because government reserved the right to amend collective agreement reached between its representatives and trade unions. This practice generates dissatisfactions and negative reactions from trade unions in the public sector. In the public sector, most wage-related conflicts occur because of government's failure to honor collective agreement.

\subsection{Respondents' Views on Government's Prerogative to Amend Collective Agreement}

Table 3 revealed that 71.1 of the respondents disagreed with the government's right to amend collective agreement in the public sector, while 23.1 percent of the respondents agreed that government has the right to mend collective agreement, and 5.8 percent of the respondents were undecided on government's right to amend collective agreement in the public sector. From this distribution majority of the respondents disagreed with government's prerogative to amend collective agreement because it accords government the opportunity to dishonor collective agreement.

\subsection{Respondents' Views on Government Regulation of Collective Bargaining}

Table 3 revealed that 76.6 percent of the respondents disagreed that government regulation of collective bargaining process is essential, 14 percent of the respondents agreed that government regulation of collective bargaining is essential, while 9.7 percent of the respondents were undecided on government regulations of collective bargaining. Drawing from these distributions, majority of the respondents are of the view that employers in the public sector should not involve in the collective bargaining process. Nigeria ratified and domesticated ILO conventions 87 and 98 on freedom of association and right to collective bargaining. These conventions allow workers to form unions and association as well as collective bargaining process without any form of government's intervention.

\subsection{Respondents' Views on Collective Bargaining is an Effective Machinery in the Public Sector}

Table 3 revealed that 73 percent of the respondent disagreed that collective bargaining is an effective machinery, 21 percent of the respondents agreed that collective bargaining is an effective 
machinery in the public sector. From these distributions, majority of the respondents are of the view that collective bargaining process is not effective in the public sector.

\subsection{Respondents' Views on Implementation of Collective Agreement is Satisfactory}

Table 3 revealed that 70.5 percent of the respondents disagreed that implementation of collective agreement is satisfactory in the public sector, while 16.8 percent of the respondents agreed that that implementation of collective agreement is satisfactory in the public sector, and 12.8 percent of the respondents were undecided. From this distribution majority of the respondents are of the view that implementation of collective agreement is not satisfactory to workers in the public sector. This distribution established that implementation of collective agreement has not been satisfactory to majority of the workers in the public sector because of government regulations of collective bargaining, government prerogative to amend collective agreement and government involvement in collective bargaining process in the public sector.

\subsection{Respondents' Views on Government Always Relies on Collective Bargaining}

Table 3 shows that 46.4 percent of the respondents disagreed that government always relies on collective bargaining process, 38.6 percent of the respondents agreed that government always relies on collective bargaining process in the public sector, while 14.9 percent of the respondents were undecided.

\subsection{Respondents' Views on Dispute Usually Arises from Collective Bargaining Process}

Table 3 shows that 65.7 percent of the respondents disagreed that dispute usually arises from collective bargaining process, 15.2 percent of the respondents agreed that dispute usually arises from collective bargaining process in the public sector while 6.1 percent of the respondents were undecided in this regard. These distributions suggest that disputes usually arise from implementation of collective agreement and not from the collective bargaining process.

\subsection{Respondents' Views on Government Seldom Use Collective Bargaining to Determine Conditions of Employment}

Table 3 indicates that 64.7 percent of the respondents disagreed that government seldom use collective bargaining to determine conditions of employment, 24.3 percent of the respondents agreed that government seldom use collective bargaining to determine conditions of employment in the public sector, while 3.0 percent of the respondents were undecided along this line. These distributions revealed that most of the respondents are of the views that government use collective bargaining machinery to determine conditions of service in the public sector.

\subsection{Respondents' Views on Violations of Workers' Rights Always Arises from Failure of Collective Bargaining Process}

Table 3 revealed that 78.1 percent of the respondents disagreed that violations of workers' rights always arises from failure of collective bargaining process, 12.1 percent of the respondents agreed that violations of workers' rights always arises from failure to observe the collective bargaining process, while 9.7 percent of the respondents were undecided on Violations of Workers' Rights Always Arises from failure of Collective bargaining process. These distributions suggest that there are no violations of workers right from the failure to respect the collective bargaining process in the public sector. 
Table-4.

Respondents views on trade unions' reactions to non-implementation of collective agreement.

\begin{tabular}{l|c|c|c|c}
\hline Trade Unions' Reactions & \multicolumn{2}{|c}{ YES } & \multicolumn{2}{c}{ NO } \\
\cline { 2 - 5 } & $\begin{array}{c}\text { Number of } \\
\text { Respondents }\end{array}$ & Percent & $\begin{array}{c}\text { Number of } \\
\text { Respondents }\end{array}$ & Percent \\
\hline Complaint about Wage Policy & 308 & 93.6 & 21 & 6.4 \\
\hline Petition on Wage Policy to express & 282 & 85.7 & 47 & 14.3 \\
\hline $\begin{array}{l}\text { Issue of ultimatum to } \\
\text { dissatisfaction about wage policy }\end{array}$ & 290 & 88.1 & 39 & 11.9 \\
\hline $\begin{array}{l}\text { Strike as a result of wage or } \\
\text { allowance }\end{array}$ & 212 & 64.4 & 112 & 35.6 \\
\hline $\begin{array}{l}\text { Sabotage to show disagreement with } \\
\text { wage policy }\end{array}$ & 297 & 90.3 & 32 & 9.7 \\
\hline $\begin{array}{l}\text { Demonstration against unfavorable } \\
\text { wage policy }\end{array}$ & 301 & 91.5 & 28 & 8.5 \\
\hline $\begin{array}{l}\text { Protest as a result of unfavorable } \\
\text { wage policy }\end{array}$ & 223 & 68 & 105 & 32 \\
\hline $\begin{array}{l}\text { Acceptance of wage policy in good } \\
\text { faith }\end{array}$ & 176 & 54 & 152 & 46 \\
\hline $\begin{array}{l}\text { Commendation of government for a } \\
\text { good wage policy }\end{array}$
\end{tabular}

Source: Research survey, 2020.

Table 4 shows respondents' views on trade unions' reactions to wage determination process in the public sector. From the distribution 93.6 per cent of the respondents claimed that reaction occurred by complaint about wage policy, 90.3 per cent of the respondents claim that reaction occurred by demonstration against unfavorable wage policy, 91.5 per cent of the respondents claimed that reaction occurred by protest against unfavorable wage policy while 88.1 per cent of the respondents claimed that reaction occurred by strike against wage or allowance.

This distribution reveals different forms of trade unions' negative reactions including complaints $(93.6 \%)$, protests $(91.5 \%)$, demonstration $(90.3 \%)$, and strike $(88.1 \%)$ followed by issuance of ultimatum $(85.2 \%)$, petition $(68.0 \%)$ and sabotage $(64.4 \%)$. Also, the trade unions' positive reactions included acceptance of wage policy in good faith $(68.0 \%)$ and commendation of government for a good wage policy $(54.0 \%)$

\subsection{Regression Analysis Results}

It was hypothesised that non-implementation of collective bargaining agreement does not affect trade unions' reactions in the Lagos State public sector. A regression analysis of the data was carried out using SPSS version 20, considering the trade unions reactions as the criterion variable and nonimplementation of collective bargaining agreement as the predictor variable.

The result of the regression indicated the predictor explained $4.8 \%$ of the variance in the criterion variable. $\left(\mathrm{R}^{2}=0.48 ; \mathrm{F}(1,328)=16.435, \mathrm{p}<0.05\right)$. It was found that non-implementation of collective bargaining agreement significantly affect trade unions' reactions in the Lagos State public sector at $(\beta=0.219, \mathrm{p}<0.05)$.

This finding also provided empirical support to Omisore (2011) observation that in Nigeria, events have shown that government has poor attitude to workers' demands as oftentimes, it breaches collective agreements signed with labour unions, thereby leading to reactions on the part of labour unions such as strikes or industrial action and other forms of industrial disputes. 


\section{Conclusion and Recommendations}

The outcome of the current study revealed that the non-implementation of collective bargaining agreements has implications for trade unions' reactions and this is consistent with the studies of Fairris (2003); Cramton et al. (1999); Ferreiro (2004) and the study of Blakemore et al. (1986). The results of the descriptive data analyses revealed that the implementation of collective agreement is not effective in the Lagos State public sector because government reserved the right to amend collective agreements reached with trade unions.

This practice generates dissatisfactions and negative reactions from trade unions in the public sector. In the public sector most wage related conflicts occur because of government's failure to honour collective agreement.

In essence, amendment of collective agreement had in the past resulted in strikes. For instance, the Academic Staff Union of Universities (ASUU) strike of 2013 on the failure of the Federal Government of Nigeria to implement the 2009 agreement.

The Nigerian Medical Association was on strike on several occasions owing to the Government's failure to implement collective agreement. In conclusion, most of the respondents were of the view that government is not always sincere in the implementation of the collective agreements jointly signed or entered into with labour unions. Arising from the findings of the study, it is hereby recommended that to foster cordial labour- management relationship and to promote industrial harmony, governments at all levels should not ignore collective agreements freely entered into with labour unions and should uphold the sanctity of collective agreements if the country is to realise its developmental objectives and to attract foreign direct investments.

\section{Sponsor}

This study was funded and sponsored partly by University of Lagos and Lagos Sate scholarship.

\section{References}

Adams, J. S. (1965). Injustice in social exchange', in Berkowitz, L (ed) Advances in experimental and social psychology. Academic Press.

Barbie, E. (2007). The practice of social research (1 1 th ed.). Wadsworth: Cengage Learning.

Blakemore, A. E., Hunt, J. C., \& Kiker, B. (1986). Collective bargaining and union membership effects on the wages of male youths. Journal of Labor Economics, 4(2), 193-211.

Cahuc, Postel-Vinay, \& Robin. (2006). Supplement to wage bargaining with on -the-job search: Theories and evidence, econometric society.

Chamberlain, N., \& Kuhn, J. (1965). Collective bargaining. New York: McGraw-Hill.

Cramton, P., Gunderson, M., \& Tracy, J. (1999). The effect of collective bargaining legislation on strikes and wages. Review of Economics and Statistics, 81(3), 475-487.

Fairris, D. (2003). Unions and wage inequality in Mexico. ILR Review, 56(3), 481-497.

Fajana, S. (2002). Industrial relations in Nigeria: Theories and features. Lagos: Nigeria. Labofin and Company.

Fajana., S. (2000). Functioning of the Nigerian labor market. Lagos: Labofin and Company.

Fapohunda, T. (2012). Comparative analysis of wage determination in unionized and non-unionized organizations in Nigeria. Educational Research, 3(1), 072-079.

Fashoyin, T. (1992). Industrial relations in Nigeria. Lagos: Longman Nigeria Plc.

Ferreiro, J. (2004). Decentralized versus centralized collective bargaining: is the collective bargaining structure in Spain efficient? Journal of Post Keynesian Economics, 26(4), 695-728.

Freeman, R. B., \& Medoff, M. L. (1985). What do unions do? Industrial and Labour Relations Review, 38(2), $244-263$.

Guardian Newspaper. (2013). Nigerian medical association strike action in Lagos State, June 13, 2013.

Iwunze, V. (2013). The unenforceability of collective agreements under Nigerian labor jurisprudence: The paradox of agreement without agreement. International Journal of Advanced Legal Studies and Governance, 4(3), 2-13.

Kahn, L. M. (1997). Collective bargaining and the interindustry wage structure: International evidence. Economica, 65(260), 507-534.

Kaufman, B. (2013). Sidney and Beatrice Webb's institutional theory of labor markets and wage determination. Industrial Relations: A Journal of Economy and Society, 52(3), 765-791.

Kish, L. (1965). Survey sampling. New York: Wiley.

Klaff, D. B., \& Ehrenberg, R. G. (2003). Collective bargaining and staff salaries in American colleges and universities. ILR Review, 57(1), 92-104. Available at: https://doi.org/10.2307/3590983. 
Kohn, K., \& Lembcke, A. C. (2007). Wage distributions by bargaining regime. AStA Wirtschafts-und Sozialstatistisches Archiv, 1(3-4), 247-261. Available at: https://doi.org/10.1007/s1 1943-007-0023-6.

Mullins, L. (2007). Management and organizational behavior. Essex: Pearson Education Limited.

Omisore, D. (2011). Breached agreements: Threat to management-union relationship. Medwell Journals, 6(4), $299-306$.

Otobo, D. (1986). Bureaucratic elites and public sector wage bargaining in Nigeria. The Journal of Modern African Studies, 24(1), 101-126.

Training and Pension Annual Digest Bulletin. (2013). Lagos state ministry of establishment

Yamane, T. (1967). Statistics: An introductory analysis (2nd ed.). New York: Harper and Row. 